\title{
Batasan Ketentuan Asas Onbekwaam Dalam Pembatalan Akta Wasiat Yang Dibuat Di Hadapan Notaris
}

\section{Imawati Latifah}

Magister Kenotariatan Fakultas Hukum Universitas Islam Indonesia Yogyakarta Indonesia Jln. Cik Di Tiro No. 1 Yogyakarta Indonesia mawatilatifah@gmail.com

Key Word: $\begin{aligned} & \text { Abstract } \\ & \text { Authentic deed } \\ & \text { cancellation, legal }\end{aligned}$ This study aims to examine the limitations of the provisions of the onbekwaam
capacity, onbekwaam the cancellation of wills made before a notary. This research uses the
principle
application of positive legal norms. The data collection technique in this study was
carried out by means of document studies or literature studies by searching,
analyzing, and combining material sourced from laws and regulations, books, and
other documents aimed at obtaining secondary data relevant to the problems
studied. The problem in this study is how the limitations of the onbekwaam
provisions in the cancellation of wills made before a Notary with a Court Decision
and why the judge decision in the case of Decision Number
53/Pdt.G/2012/PN.Jkt.Sel which states that the will is canceled and non-binding
can result in a will that is made before the notary is considered invalid. The results
of this study conclude that the principle of incompetence that is used as the basis for
the judge decision is no longer based on the legal age limit, but a situation where
legal competence can be declared lost or judged to be an incompetence due to certain
conditions, namely people who are placed under guardianship. , which can occur
due to mental disorders such as neurosis, because the person's actions are abnormal
according to ordinary standards, including mental disorders

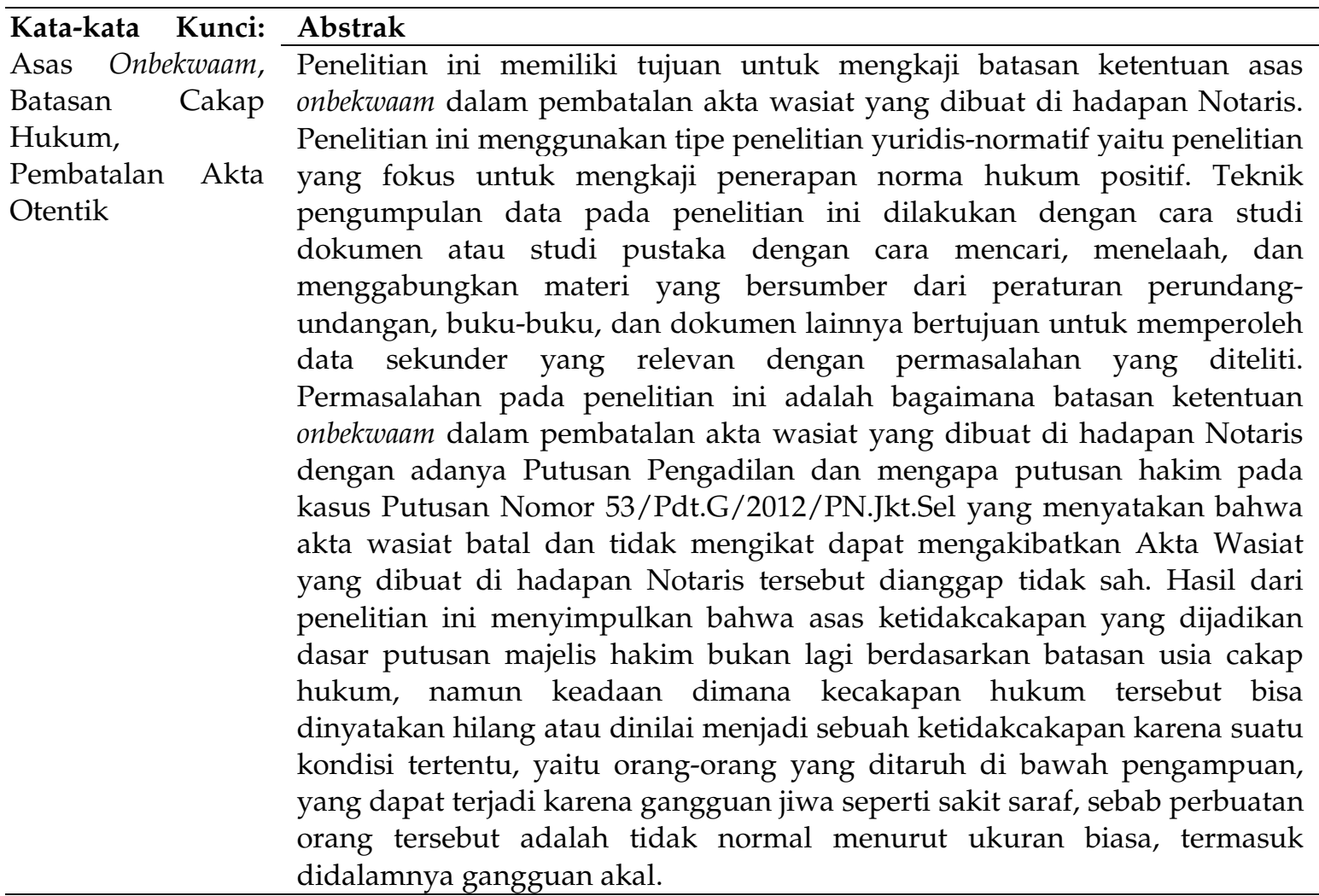




\section{Pendahuluan}

Pembuatan akta wasiat adalah salah satu perbuatan hukum yang dapat dilakukan oleh subjek hukum dengan syarat-syarat tertentu. Manusia sebagai subjek hukum adalah pemegang hak dan kewajban dalam melakukan perbuatan hukum. Salah satu syarat sah untuk dapat melakukan suatu perbuatan hukum adalah sudah cakap hukum atau cakap untuk melakukan perbuatan hukum. Kecakapan seringkali dikaitkan dengan kedewasaan seseorang atau erat kaitannya dengan usia seseorang untuk menjadi suatu tolak ukur dapat melakukan suatu perbuatan hukum.

Pasal 1329 Kitab Undang-Undang Hukum Perdata telah mengatur bahwa setiap orang berwenang untuk membuat perikatan, kecuali jika ia dinyatakan tidak cakap untuk hal itu. Kriteria seseorang yang dinyatakan tidak cakap dalam membuat perikat diatur lebih lanjut dalam Pasal 1330 Kitab Undang-Undang Hukum Perdata, antara lain adalah anak yang belum dewasa, orang yang ditaruh di bawah pengampuan, dan perempuan yang telah kawin dalam hal-hal yang ditentukan undang-undang dan pada umumnya semua orang yang oleh undang-undang dilarang untuk membuat persetujuan tertentu.

Mendasarkan pada ketentuan norma tersebut, terdapat sebuah perkara yang telah diputus melalui Putusan Nomor 53/Pdt.G/2012/PN.Jkt.Sel. Notaris sebagai tergugat dalam kasus ini terbukti membuat surat wasiat atas kehendak almarhum Tuan Tan Malaka yang pada saat itu terbukti dalam keadaan sakit dan dinyatakan tidak cakap melakukan perbuatan hukum sehingga Akta Wasiat tersebut dianggap batal dan tidak mengikat. Pada salah satu amar putusan menyebutkan bahwa Notaris sebagai tergugat dalam kasus ini berkewajiban untuk mencoret Akta Wasiat Nomor 5 tertanggal 9 Oktober 2009 dari daftar Akta Wasiat yang dibuat olehnya berdasarkan Pasal 16 huruf (i) Undang-Undang Nomor 30 Tahun 2004 tentang Jabatan Notaris.

Putusan Nomor 53/Pdt.G/2012/PN.Jkt.Sel. pada akhirnya memutus dan menetapkan bahwa Notaris selaku tergugat dalam kasus ini melakukan perbuatan melawan hukum dan menyatakan bahwa Akta Wasiat Nomor 5 tertanggal 9 Oktober 2009 batal dan tidak mengikat dikarenakan almarhum Tuan Tan Malaka selaku penghadap pada pembuatan akta wasiat tersebut dinyatakan tidak cakap untuk melakukan suatu perbuatan hukum. Selanjutnya Notaris atau tergugat dalam kasus ini diharuskan untuk mencabut Akta Wasiat Nomor 5 tertanggal 9 Oktober 2009 dari buku daftar wasiat Subdit Harta Peninggalan Direktorat Perdata Kementerian Hukum dan Hak Asasi Manusia Republik Indonesia.

Permasalahan utama yang terdapat pada kasus Putusan Nomor 53/Pdt.G/2012/PN.Jkt.Sel. ini terletak pada sejauh mana batasan ketentuan asas onbekwaam yang menjadi pertimbangan hakim dalam memutus perkara dengan amar putusan batal dan tidak mengikat akta wasiat yang dibuat di hadapan Notaris. Hal ini berkaitan erat dengan Pasal 39 ayat (1) Undang-Undang Nomor 2 Tahun 2014 juncto Undang-Undang Nomor 30 Tahun 2004 tentang Jabatan Notaris. 


\section{Rumusan Masalah}

1. Bagaimana batasan ketentuan asas onbekwaam dalam pembatalan akta wasiat yang dibuat di hadapan Notaris dengan adanya Putusan Pengadilan?

2. Mengapa putusan hakim pada kasus Putusan Nomor 53/Pdt.G/2012/PN.Jkt.Sel yang menyatakan bahwa akta wasiat batal dan tidak mengikat mengakibatkan Akta Wasiat yang dibuat di hadapan Notaris tersebut dianggap tidak sah?

\section{Tujuan Penelitian}

1. Untuk mengetahui bagaimana batasan ketentuan asas onbekwaam dalam kasus pembatalan akta wasiat yang dibuat di hadapan Notaris dengan adanya Putusan Pengadilan yang menyatakan batal dan tidak mengikat akta wasiat tersebut.

2. Untuk mengetahui mengapa putusan hakim pada kasus Putusan Nomor 53/Pdt.G/2012/PN.Jkt.Sel yang menyatakan bahwa akta wasiat batal dan tidak mengikat mengakibatkan Akta Wasiat yang dibuat di hadapan Notaris tersebut dianggap tidak sah.

\section{Metode Penelitian}

Penelitian ini menggunakan jenis penelitian yuridis-normatif yaitu penelitian yang fokus untuk mengkaji penerapan kaidah-kaidah atau norma-norma hukum positif. ${ }^{1}$ Pembahasan utama dalam penelitian ini adalah penelitian terkait asas hukum. Jenis penelitian ini menggunakan pendekatan dengan konsep legis positivis yang memandang hukum identik dengan norma-norma atau kaidah-kaidah tertulis yang dibuat dan diundangkan oleh lembaga atau pejabat yang berwenang.

Analisis data dilakukan dengan menghimpun data bersumber dari peraturan perundang-undangan yang berlaku dan data kepustakaan yang berkaitan dengan asas onbekwaam serta berkaitan dengan putusan pengadilan yang dapat menyatakan akta wasiat yang dibuat di hadapan Notaris batal dan tidak mengikat. Data dalam penelitian ini disajikan secara deskriptif dengan menjabarkan teori, asas-asas, dan norma atau ketentuan hukum yang berhubungan dengan kasus pembatalan akta yang dibuat di hadapan Notaris dengan adanya Putusan Pengadilan.

\section{Hasil Penelitian dan Pembahasan}

\section{Batasan Ketentuan Asas Onbekwaam dalam Pembatalan Akta Wasiat yang Dibuat di Hadapan Notaris dengan adanya Putusan Pengadilan}

Kecakapan merupakan salah satu unsur melakukan suatu perbuatan hukum. Kecakapan dalam hal ini berarti kondisi dimana seseorang atau subjek hukum dapat dinyatakan cakap untuk bertindak atau untuk melakukan perbuatan hukum. Kecakapan biasanya berhubungan erat dengan kedewasaan seseorang, karena dalam hukum seseorang dapat dinyatakan cakap ketika mencapai suatu titik kedewasaan tertentu

\footnotetext{
${ }^{1}$ Johny Ibrahim, Teori dan Metodologi Penelitian Hukum Normatif, Bayumedia Publishing, Malang, 2006, hlm.
} 
sebagaimana diatur dalam peraturan perundang-undangan yang berlaku. Seseorang harus dinyatakan cakap hukum untuk dapat melakukan suatu perbuatan hukum tertentu, termasuk salah satunya dalam pembuatan akta wasiat yang dibuat di hadapan Notaris.

Kitab Undang-Undang Hukum Perdata memberikan definisi kedewasaan tidak lepas dengan umur atau usia kedewasaan seseorang. Sebagaimana disebutkan dalam Pasal 330 Kitab Undang-Undang Hukum Perdata yang berbunyi, "belum dewasa adalah mereka yang belum mencapai umur genap 21 tahun atau belum menikah". Bunyi pasal tersebut mempunyai arti bahwa seseorang yang telah mencapai umur 21 tahun atau seseorang yang sudah menikah sebelum mencapai usia itu dapat dianggap atau dikatakan sudah dewasa, dan karena kedewasaan sering dikaitkan dengan tingkat kecakapan melakukan tindakan hukum maka dengan adanya pasal tersebut dapat disimpulkan bahwa mereka yang telah mencapai usia 21 tahun (atau sudah menikah) sudah dapat merumuskan kehendaknya dengan benar dan sudah dapat menyadari akibat hukum dari perbuatannya, dan karenanya sejak itu mereka dinyatakan cakap untuk bertindak dalam hukum (handelings-bekwaam). ${ }^{2}$

Batasan kecakapan atau cakap hukum dalam Undang-Undang Nomor 30 Tahun 2004 tentang Jabatan Notaris menyatakan bahwa syarat untuk menjadi penghadap dan saksi telah berumur 18 tahun dan cakap melakukan perbuatan hukum. Definisi tersebut memberikan suatu pengertian bahwa seseorang yang telah genap berumur 18 tahun dianggap oleh pembuat undang-undang sebagai orang yang telah dapat dibebani tanggung jawab hukum, sebagaimana diatur dalam Pasal 39 ayat (1) berikut : “ Penghadap harus memenuhi syarat sebagai berikut: a. paling sedikit berumur 18 (delapan belas) tahun atau telah menikah; dan b. cakap melakukan perbuatan hukum.

Penambahan syarat "cakap melakukan perbuatan hukum" dalam UndangUndang Nomor 30 Tahun 2004 tentang Jabatan Notaris dapat ditafsirkan bahwa kecakapan yang dimaksud bukanlah kecakapan berdasarkan batas umur, namun kecakapan yang digantungkan pada syarat lain, yaitu tidak berada dibawah pengampuan, karena mengenai batas umur telah diatur secara khusus dan ditegaskan dalam syarat umur, yang berbeda dengan ketentuan dalam Kitab Undang-Undang Hukum Perdata, yaitu 18 tahun sebagaimana disebutkan dalam poin huruf (a). ${ }^{3}$

Penting untuk mengetahui sejauh mana batasan ketentuan asas Onbekwaam yang diterapkan dalam kasus pembatalan akta wasiat yang dibuat di hadapan Notaris, khususnya pada kasus Putusan Nomor 53/Pdt.G/2012/PN.Jkt.Sel. yang salah satu amar putusannya menyatakan bahwa Akta Wasiat Nomor 5 tertanggal 9 Oktober 2009 batal dan tidak mengikat dikarenakan almarhum Tuan Tan Malaka selaku penghadap pada pembuatan akta wasiat tersebut dinyatakan tidak cakap untuk melakukan suatu perbuatan hukum.

2 Ade Maman Suherman - J.Satrio, Penjelasan Hukum tentang Batasan Umur (Kecakapan dan Kewenangan Bertindak Berdasar Batasan Umur), National Legal Reform Program, Jakarta, 2010, hlm. 9

${ }^{3}$ Ibid., hlm. 92. 
Putusan Nomor 53/Pdt.G/2012/PN.Jkt.Sel. pada salah satu amar putusannya menyebutkan bahwa Notaris sebagai tergugat dalam kasus ini berkewajiban untuk mencoret Akta Wasiat Nomor 5 tertanggal 9 Oktober 2009 dari daftar Akta Wasiat yang dibuat olehnya berdasarkan Pasal 16 huruf (i) Undang-Undang Nomor 30 Tahun 2004 tentang Jabatan Notaris. Hal ini dikarenakan Notaris sebagai tergugat dalam kasus ini terbukti membuat surat wasiat atas kehendak almarhum Tuan Tan Malaka yang pada saat itu terbukti dalam keadaan sakit dan dinyatakan tidak cakap melakukan perbuatan hukum sehingga Akta Wasiat tersebut dianggap batal dan tidak mengikat.

Pada 9 Oktober 2009, almarhum Tuan Tan Malaka membuat surat wasiat di hadapan Notaris sebagaimana dinyatakan dan tertuang dalam Akta Wasiat Nomor 5, 9 Oktober 2009. Akta Wasiat tersebut berisikan mengenai kehendak almarhum Tuan Tan Malaka yang memberikan wasiat atas sejumlah bidang tanah kepada beberapa ahli waris almarhum Tuan Tan Malaka sendiri. Penggugat dalam kasus ini yang merupakan salah satu anak dari almarhum Tuan Tan Malaka yang juga merupakan salah satu ahli waris dari Tuan Tan Malaka sendiri yang menyatakan bahwa pada saat pembuatan Akta Wasiat tersebut, almarhum Tuan Tan Malaka dalam keadaan tidak cakap untuk melakukan perbuatan hukum dengan mengajukan bukti-bukti sebagai berikut:

1. Surat Keterangan Medis tanggal 6 Juni 2006 yang ditandatangani oleh dr. George Dewanto, Sp.S (Dokter Spesialis Saraf Rumah Sakit Pluit) yang menyebutkan bahwa Tuan Tan Malaka telah mengalami stroke, diabetes, hipertensi, dan sebagai akibat dari penyakit tersebut daya cognitive serta fungsi motorik Tuan Tan Malaka menjadi tidak normal. Sehingga dengan penyakit yang dideritanya tersebut Tuan Tan Malaka atas rekomendasi dr. Meliani Yustina selaku dokter spesialis saraf agar dirawat di Rumah Sakit.

2. Surat Keterangan Hasil Pemeriksaan Kesehatan tanggal 1 April 2008 yang ditandatangani oleh dr. Armahida Kusriana, Dokter pada Bidang Kedokteran dan Kesehatan Polda Metro Jaya yang menyatakan bahwa kondisi Tuan Tan Malaka dalam keadaan pikun dan oleh dr. Sudarto Apit, Sp.PD. diterbitkan surat pengantar tertanggal 22 Juni 2009 yang merekomendasikan agar Tuan Tan Malaka dirawat di Rumah Sakit Pantai Indah Kapuk.

Tergugat dan Turut Tergugat menolak gugatan Penggugat tersebut dengan alasan pada 9 Oktober 2009 atau pada saat dibuatnya Akta Wasiat tersebut Tuan Tan Malaka dalam keadaan cakap sehingga Akta Wasiat Nomor 5, 9 Oktober 2009 adalah sah. Hal ini ditegaskan pada jawaban gugatan bahwa pada waktu almarhum Tuan Tan Malaka membuat Akta Wasiat a quo adalah dalam keadaan sehat dan datang menghadap Notaris selaku tergugat dalam kasus ini sebagaimana layaknya dan formalnya pembuatan suatu akta dimana almarhum Tuan Tan Malaka menunjukkan dokumen-dokumen yang dibutuhkan dalam pembuatan Akta Wasiat a quo. Notaris berpedoman kepada kebenaran formal dari syarat-syarat yang harus dipenuhi oleh penghadap yang dalam hal ini telah dipenuhi oleh almarhum Tuan Tan Malaka dimana yang bersangkutan melakukan sendiri dan membawa serta menunjukkan sendiri seluruh dokumen-dokumen yang diperlukan dalam membuat suatu akta dalam keadaan sadar dan tanpa adanya suatu paksaan dari pihak manapun. 
Notaris sebagai tergugat dalam kasus ini juga menyatakan bahwa bukti yang diajukan oleh penggugat berupa Surat-Surat Keterangan Medis yang disebutkan adalah terjadi sebelum pembuatan Akta Wasiat a quo, bukan bersamaan dengan pembuatan Akta Wasiat a quo. Selain itu juga tidak ada satupun yang menyatakan bahwa almarhum Tuan Tan Malaka berada dalam kondisi sakit yang permanen yang kemudian menjadikan tidak cakap untuk melakukan suatu perbuatan hukum.

\section{Akta Wasiat Batal dan Tidak Mengikat dalam Putusan Nomor 53/Pdt.G/2012/PN.Jkt.Sel}

Putusan Nomor 53/Pdt.G/2012/PN.Jkt.Sel. memutus dan menetapkan bahwa Notaris selaku tergugat dalam kasus ini melakukan perbuatan melawan hukum dan menyatakan bahwa Akta Wasiat Nomor 5, 9 Oktober 2009 batal dan tidak mengikat dikarenakan almarhum Tuan Tan Malaka selaku penghadap pada pembuatan akta wasiat tersebut dinyatakan tidak cakap untuk melakukan suatu perbuatan hukum. Selanjutnya Notaris atau tergugat dalam kasus ini diharuskan untuk mencabut Akta Wasiat Nomor 5, 9 Oktober 2009 dari buku daftar wasiat Subdit Harta Peninggalan Direktorat Perdata Kementerian Hukum dan Hak Asasi Manusia Republik Indonesia.

Putusan majelis hakim ini juga sesuai dengan penyimpangan syarat sahnya pembuatan surat wasiat berdasarkan Pasal 895 Kitab Undang-Undang Hukum Perdata yang menyebutkan bahwa untuk dapat membuat atau mencabut surat wasiat, seseorang harus mempunyai budi akal dalam hal ini dapat juga dikatakan cakap hukum, artinya seseorang tidak boleh membuat surat wasiat apabila seseorang itu berada dalam kondisi tidak cakap hukum atau dalam kasus ini pemberi wasiat memiliki sakit ingatan sehingga tidak dapat berpikir secara teratur.

Pembatalan akta wasiat yang dibuat di hadapan Notaris dapat dilakukan dengan adanya Putusan Pengadilan yang berarti sebelumnya harus ada gugatan terlebih dahulu dari pihak yang menyatakan bahwa akta tersebut tidak sah. Hal ini tidak dapat dipisahkan dengan prinsip hukum dalam Putusan Pengadilan yaitu asas Res Judicata Pro Veritate Habetur. Res Judicata sebagai sebuah kata sebagaimana disebutkan dalam Black Law Dictionary Seventh Edition memiliki definisi "an issue that has been definitively settled by judical decision" yang berarti kasus yang telah diputuskan secara definitif atau pasti.

Sudikno Mertokusumo menyebutkan bahwa asas Res Judicata Pro Veritate Habetur memiliki arti bahwa apa yang telah diputus Hakim harus dianggap benar. Apabila terdapat saksi palsu yang diajukan dalam persidangan dan majelis hakim memutus perkara berdasarkan keterangan saksi palsu tersebut, jelas putusannya tidak berdasarkan kesaksian yang sebenarnya, namun putusan tersebut tetap harus dianggap benar, sampai memperoleh kekuatan hukum yang tetap atau diputus lain oleh pengadilan yang lebih tinggi (apabila perkara tersebut diajukan banding atau kasasi). ${ }^{4}$

Apabila terdapat suatu gugatan yang menyatakan bahwa akta Notaris dinyatakan tidak sah, maka harus dibuktikan pernyataan tidak sah tersebut baik dari aspek lahiriah,

\footnotetext{
${ }^{4}$ Sudikno Mertokusumo, Penemuan Hukum: Sebuah Pengantar, Liberty, Yogyakarta, 2006, hlm. 7
} 
formal, dan material. Jika pihak yang mengajukan gugatan tidak dapat membuktikannya, maka akta yang bersangkutan tetap sah mengikat bagi para pihak yang berkepentingan atas akta tersebut. Sebaliknya apabila dalam persidangan pihak yang mengajukan gugatan dapat membuktikan terdapat aspek yang menyebabkan cacatnya akta, maka akta tersebut dapat menjadi akta yang terdegradasi atau berubah statusnya menjadi akta di bawah tangan, atau bahkan akta tersebut dapat dinyatakan batal demi hukum oleh majelis Hakim dalam persidangan.

Asas Praduga Sah pada Akta Notaris sebagaimana telah dibahas oleh Habib Adjie pada bukunya yang menyebutkan bahwa dalam pembuatan akta Notaris ada 2 hal yang membuat akta Notaris dikatakan sah. Pertama, bahwa Notaris berwenang membuat akta sesuai dengan keinginan pihak yang menghadap. Kedua, secara lahiriah, formal, dan material telah sesuai dengan aturan hukum tentang pembuatan akta Notaris. Akta Notaris sebagai produk dari pejabat publik maka penilaian terhadap akta Notaris harus dilakukan dengan asas praduga sah (vermoeden van rechmatigheid) atau presumptio iustae causa.

Asas ini dipergunakan untuk menilai akta Notaris, yang berarti akta Notaris harus dianggap sah sampai ada pihak yang menyatakan bahwa akta tersebut tidak sah. ${ }^{5} \mathrm{Hal}$ ini sesuai dengan teori akta Notaris dapat dinyatakan batal demi hukum atau dapat diyatakan tidak sah oleh suatu sebab tertentu. Hakim secara ex officio pada dasarnya tidak dapat membatalkan suatu akta Notaris atau akta otentik lainnya jika tidak ada pihak yang meminta suatu pembatalan, karena hakim tidak boleh memutuskan perkara perdata termasuk batalnya akta apabila tidak ada permohonan pembatalan akta. ${ }^{6}$ Jika terdapat pihak yang meminta pembatalan akta, maka kemudian akta otentik tersebut dapat dibatalkan oleh hakim jika dapat dibuktikan ketidakabsahannya. Mengenai pembatalan isi akta, seorang Notaris bertindak untuk mencatat apa saja yang dikemukakan oleh para penghadap dan tidak wajib untuk menyelidiki kebenaran materiil atas isi akta tersebut.

Apabila suatu akta Notaris dipermasalahkan oleh para pihak dalam hal ini baik pihak-pihak yang membuat akta, maupun pihak ketiga yang masih berkaitan dengan akta tersebut maka:

1. Para pihak dapat datang kembali ke Notaris yang bersangkutan untuk membuat akta pembatalan atas akta yang dipermasalahkan tersebut, dengan tujuan akta yang dibatalkan oleh para pihak sudah tidak lagi mengikat para pihak dan para pihak menanggung segala akibat dari pembatalan akta tersebut;

2. Apabila terdapat pihak yang tidak sepakat atas permasalahan suatu akta dan tidak setuju atas suatu pembatalan yang dapat dilakukan secara mandiri di Notaris, maka salah satu pihak dapat menggugat pihak lainnya ke Pengadilan baik dengan gugatan untuk mendegradasi akta Notaris tersebut menjadi akta di bawah tangan, maupun gugatan untuk membatalkan akta Notaris yang bersangkutan. Hal yang demikian ini

5 Habib Adjie, Sanksi Perdata dan Administratif terbadap Notaris sebagai Pejabat Publik. Refika Aditama, Bandung, 2017, hlm. 79.

${ }^{6}$ Sudikno Mertokusumo, Op. Cit., hlm.126. 
tergantung hasil pembuktian dalam persidangan dan berdasarkan pertimbangan hakim dalam memutuskan suatu perkara berkaitan dengan akta Notaris tersebut.

Putusan pengadilan yang menyatakan bahwa akta otentik berupa Akta Wasiat yang dibuat di hadapan Notaris tersebut dianggap batal dan tidak mengikat dapat dikatakan akta wasiat ini dianggap tidak pernah ada atau tidak pernah dibuat oleh Tuan Tan Malaka sehingga tidak dapat mengikat pihak-pihak yang bersangkutan untuk mengikuti isi akta tersebut. Hal ini sejalan dengan prinsip yang telah disebutkan oleh Sudikno Mertokusumo dalam bukunya yang menyatakan bahwa asas Res Judicata Pro Veritate Habetur memiliki arti bahwa apa yang telah diputus Hakim harus dianggap benar. Apabila terdapat saksi palsu yang diajukan dalam persidangan dan majelis hakim memutus perkara berdasarkan keterangan saksi palsu tersebut, jelas putusannya tidak berdasarkan kesaksian yang sebenarnya, namun putusan tersebut tetap harus dianggap benar, sampai memperoleh kekuatan hukum yang tetap atau diputus lain oleh pengadilan yang lebih tinggi (apabila perkara tersebut diajukan banding atau kasasi). ${ }^{7}$ Putusan Hakim dalam perkara ini menyatakan bahwa akta wasiat yang dibuat di hadapan Notaris dinyatakan batal dan tidak mengikat karena penghadap Tuan Tan Malaka pada saat membuat akta tersebut terbukti dalam keadaan tidak cakap hukum.

Asas Praduga Sah pada Akta Notaris sebagaimana telah dibahas oleh Habib Adjie pada bukunya yang menyebutkan bahwa dalam pembuatan akta Notaris ada 2 hal yang membuat akta Notaris dikatakan sah. Pertama, bahwa Notaris berwenang membuat akta sesuai dengan keinginan pihak yang menghadap. Kedua, secara lahiriah, formal, dan materiil telah sesuai dengan aturan hukum tentang pembuatan akta Notaris. Akta Notaris sebagai produk dari pejabat publik maka penilaian terhadap akta Notaris harus dilakukan dengan asas praduga sah (vermoeden van rechmatigheid) atau presumptio iustae causa. Asas ini dipergunakan untuk menilai akta Notaris, yang berarti akta Notaris harus dianggap sah sampai ada pihak yang menyatakan bahwa akta tersebut tidak sah. ${ }^{8}$

Kedua asas ini mendukung Putusan Pengadilan yang menyatakan bahwa akta wasiat yang dibuat di hadapan Notaris batal dan tidak mengikat. Putusan Pengadilan tersebut sesuai dengan prinsip Res Judicata Pro Veritate Habetur yang mana putusan pengadilan dianggap benar dan mengikat para pihak yang bersangkutan sampai memperoleh kekuatan hukum yang tetap atau diputus lain oleh pengadilan yang lebih tinggi (apabila perkara tersebut diajukan banding atau kasasi). Kemudian akta wasiat yang dibuat di hadapan Notaris menjadi tidak sah karena adanya Putusan Pengadilan tersebut sehingga Asas Praduga Sah akta wasiat yang dibuat di hadapan Notaris tersebut menjadi gugur.

\section{Penutup}

Batasan ketidakcakapan yang dijadikan dasar putusan majelis hakim bukan lagi berdasarkan batasan usia cakap hukum, namun keadaan dimana kecakapan hukum

${ }^{7}$ Ibid., hlm. 7

${ }^{8}$ Habib Adjie, Loc. Cit. 
tersebut bisa dinyatakan hilang atau dinilai menjadi sebuah ketidakcakapan karena suatu kondisi tertentu. Tuan Tan Malaka pada saat menghadap dan membuat akta wasiat di hadapan Notaris pada tanggal 9 Oktober 2009 terbukti dalam kondisi ketidakcakapan sungguh-sungguh (feitelijke handelings onbekwamheid) yaitu orang-orang yang ditaruh di bawah pengampuan (curatele), yang dapat terjadi karena gangguan jiwa seperti sakit saraf, sebab perbuatan orang tersebut adalah tidak normal menurut ukuran biasa, termasuk didalamnya gangguan akal. Hal ini dibuktikan dengan dokumen pendukung berupa surat keterangan diagnosa yang menyatakan bahwa Tuan Tan Malaka dalam keadaan tidak cakap hukum. Sebagaimana disebutkan pada pasal 39 Undang-Undang Nomor 30 Tahun 2004 tentang Jabatan Notaris mengenai syarat penghadap, Tuan Tan Malaka dengan bukti tersebut tidak lagi memenuhi syarat penghadap harus dalam keadaan cakap hukum saat membuat akta di hadapan Notaris. Hal ini juga sesuai dengan penyimpangan syarat sahnya pembuatan surat wasiat berdasarkan Pasal 895 Kitab Undang-Undang Hukum Perdata yang menyebutkan bahwa untuk dapat membuat atau mencabut surat wasiat, seseorang harus mempunyai budi akal, artinya seseorang tidak boleh membuat surat wasiat apabila seseorang itu memiliki sakit ingatan sehingga tidak dapat berpikir secara teratur.

Putusan Pengadilan mengenai pembatalan akta wasiat yang dibuat di hadapan Notaris dapat mengakibatkan akta wasiat dianggap tidak sah karena putusan pengadilan memiliki kekuatan untuk membatalkan akta otentik yang tidak sesuai dengan peraturan perundang-undangan. Asas Praduga Sah pada Akta Notaris (vermoeden van rechmatigheid) atau presumptio iustae causa memiliki arti bahwa akta Notaris harus dianggap sah sampai ada pihak yang menyatakan bahwa akta tersebut tidak sah. Putusan pengadilan yang menyatakan bahwa akta wasiat batal dan tidak mengikat membuat asas praduga sah ini menjadi gugur dan menjadikan akta tersebut dapat dikatakan tidak sah. Terdapat pula asas Res Judicata Pro Veritate Habetur yang memiliki arti bahwa apa yang telah diputus Hakim harus dianggap benar sampai memperoleh kekuatan hukum yang tetap atau diputus lain oleh pengadilan yang lebih tinggi (apabila perkara tersebut diajukan banding atau kasasi).

Notaris dalam menjalankan tugas harus menitik beratkan asas kehati-hatian dan asas kecermatan dalam pembuatan suatu akta otentik seperti melakukan pengenalan terhadap penghadap dengan memeriksa identitas yang diperlihatkan, menanyakan, mendengarkan, dan mencermati kehendak penghadap, serta memeriksa bukti surat yang berkaitan dengan kehendak penghadap tersebut, dan melakukan kewajiban lain yang berkaitan dengan pelaksanaan tugas jabatannya. Sikap kehati-hatian dan kecermatan Notaris menjadi penting untuk membantu dirinya mempertanggungjawabkan atas segala akta otentik yang dibuatnya apabila terjadi permasalahan atau sengketa seperti yang terjadi pada kasus yang dibahas dalam penulisan ini.

Hendaknya terdapat peraturan yang lebih jelas dan terperinci dalam hal lingkup pertanggungjawaban Notaris dimana selain memuat apa saja hal-hal yang menjadi tanggung jawab Notaris juga memuat tentang bagaimana prosedur atau tata cara pelaksanaan bagi Notaris dalam melakukan tanggung jawab tersebut serta perlindungan apa saja yang berhak didapat oleh Notaris dalam melaksanakan tanggung jawab profesi tersebut. Selama ini pemeriksaan identitas yang dilakukan oleh Notaris hanya mencakup 
pemeriksaan kartu identitas dan pengamatan Notaris sendiri berkaitan dengan kecakapan pihak yang datang ke hadapan Notaris tanpa ada instrumen lain yang dapat membantu Notaris dalam pengecekan formil khususnya dalam hal ini untuk menentukan apakah subjek hukum tersebut dapat dikatakan cakap hukum.

\section{Daftar Pustaka}

\section{Buku}

Adjie, Habib. Sanksi Perdata dan Administratif terhadap Notaris sebagai Pejabat Publik. Refika Aditama, Bandung, 2017.

Ibrahim, Johny, Teori dan Metodologi Penelitian Hukum Normatif, Bayumedia Publishing, Malang, 2006.

Mertokusumo, Sudikno, Hukum Acara Perdata Indonesia, Liberty, Yogyakarta, 2006.

\section{Jurnal}

Suherman, Ade Maman dan J. Satrio. 2010. Penjelasan Hukum tentang Batasan Umur (Kecakapan dan Kewenangan Bertindak Berdasar Batasan Umur). Jakarta: National Legal Reform Program.

\section{Peraturan perundang-Undangan}

Undang-Undang Nomor 30 Tahun 2004 tentang Jabatan Notaris

\section{Putusan Pengadilan}

Putusan Nomor 53/Pdt.G/2012/PN.Jkt.Sel. 